\title{
The View on the Sexual Education of People with Autism in Modern Greek Society
}

Nikos Apteslis*

*Correspondence: n.apteslis@gmail.com

CrossMark

$\leftarrow$ Click for updates

Head of 1st Centre of Educational \& Psychological Support in West Thessaloniki Thessaloniki, Iliados 14, 54641, Greece.

\begin{abstract}
Sexual education is not part of any formal educational program in Greece and there exist rare researches so far. People with autism have the right to grow up and be treated with respect and dignity in their adult lives and have the right of knowledge in order to be able to control their feelings and have proper social behavior. The purpose of the present study was to investigate the views of parents of children with or without autism in the sexual education of autistic children in school age. The target population was parents of children with autism and of children with typical development at school age, attending educational structures of the Greek state (school age for children with autism in Greece is from 6 to 22 years). The factors examined included the place of residence, the educational level, the profession and the gender of the parents and their views on the sexual education of children with autism. The results showed that older parents of children with or without autism were more progressive about the sexual education of children with autism. Also, the higher educational level of parents was related to greater acceptance of sexual education of children with autism. In conclusion, both groups of parents believe that sex education will help young people with autism make good sexual decisions and develop healthy interpersonal relationships.
\end{abstract}

Keywords: Children or young people with autism, sexual education, parents, demographic characteristics

\section{Introduction}

\section{Limiting the problem}

Autism spectrum disorders (ASD) affect one in 68 children in the United States (Centers for Disease Control and Prevention 2014). While early detection and intervention can improve cognitive, social, and communicative functioning $[1,39]$, core symptoms typically persist into adolescence and adulthood [9].

Considerable research has focused on promoting independence and optimizing the quality of life for adolescents and young adults with ASD $[13,16]$. Unfortunately, the areas of sexual development and sexuality of people and especially young people with ASD have been largely neglected $[2,4,25]$. In part, the absence of relevant research may occur due to conservative views of society that people with autism do not have sexual needs and do not develop sexual relations $[17,24,26]$. As a result, the parents of children with autism and professionals may think that youth with ASD lack interest in sexual relationships $[2,16]$. However, recent research indicates that individuals with ASD desire and pursue sexual relationships and engage in a variety of sexual behaviors typical of most people $[41,45]$.

Parents of children and of teenagers of typical development recognized as the primary sexuality educators and parent-child communication about sex issues is an ongoing, bidirectional process beginning early in life and continuing into early adulthood $[11,35]$. Also, parents consider being necessary for their children to have formal sex education in school mainly under the need for restriction on unwanted pregnancies and the prevention of sexually transmitted diseases $[36,39]$.

Parents of children or of the adolescences with autism, particularly concern about sexual development and behavior of their children [8]. Many of the parents are uncertain on how and when to cover sexuality-related issues with their child and what sexuality-related topics they should include $[32,33]$. They have feelings of fear and anxiety, which are mainly focussed on the supposed inappropriate behavior of their child [8,21]. As a result, parents of youth with ASD delay or avoid covering important sexuality-related topics, leaving their child to learn about those issues from various, possibly less credible, sources.

(C) 2019 Nikos Apteslis; licensee Herbert Publications Ltd. This is an Open Access article distributed under the terms of Creative Commons Attribution License (http://creativecommons.org/licenses/by/3.0). This permits unrestricted use, distribution, and reproduction in any medium, provided the original work is properly cited. 
Nikos Apteslis, Journal of Autism 2019,

Indeed, at least one study with ASD youth found that they have learned about most sexuality topics by themselves or from peers, rather than from their parents $[4,5,30]$. It is possible, parents' underestimation and unawareness to inform their adolescents about sexual issues arises from the broader view of society that people with autism do not have sexual interests and needs [38].

Research into the sexual education of young people with autism is not extensive [23,31]. Even more limited are the studies about parents' views for the sexual education of children with ASD. A short number of studies show that the personal characteristics of parents such as age, educational level [19] socio-economic situation [40] and religion [39] influenced their attitudes towards the sexual education of their children with autism. The results show that young parents with a high level of education and high socioeconomic status have a positive attitude towards the sexual education of children with autism [9]. Religion affects the attitude of the parents and it seems that usually the followers of religion adopt the belief that sexual concerns are inappropriate to discuss and much further to include them as a part in formal education [9]. In addition, a large number of studies do not include the views of the general population [3]. It would be interesting to identify if those factors also affect attitudes of parents of children with typical development and whether they consider that sex education is as important for young with autism, as they consider that it is for young with typical development [25]. The views of parents of general development children reflect the overall, general attitude of society towards sexual education and sexual rights of people with autism $[15,33]$. Only a few references to sexuality compared to the general population $[\mathbf{9 , 1 2}]$ showed that children with autism are particularly in need of appropriate sex education as well as their peers without autism, in order to be protected from sexual exploitation and abuse $[39,41]$. So, it is difficult to decide if the general population is tolerant toward sexual education of young people with autism $[14,15]$. The positive view of parents and society, in general, can be a very important element in developing appropriate educational policy and training to sex education programs for children or youth with autism [45].

\section{Methods}

\section{Objectives of the survey}

The aim of the present research is to investigate the views of parents of children with and without autism on the influence of demographic characteristics, place of residence, gender, age, education, degree of participation in the sexual education of their children, the formation of views with regard to the sexual education of children with autism.

\section{Assumptions}

1. Parents of children with or without autism consider that young people with autism should receive sexual education at school
2. The parents' age, place of residence and profession correlates to the view of the sexual education of children with autism.

3. The higher the educational level of the parents of children with autism, the higher believe that their children should receive sexual education.

\section{Participants}

Participants were total 614 and from them, 308 had children with autism from 6 to 23 years old and 306 had children with typical development from 6 to 18 years old. Children and young people with autism attended educational structures in general or special education, according to the Greek law for the education of children with special needs [1].

\section{Data collection tool}

In order to be able to collect data for the present research, a specific questionnaire invented which consisted of 3 parts (1st) Demographic features of the parents outlining their social profile as age, marital status, occupation, educational level and place of residence (2nd) Parents' views on sexual education for young people with autism about their concern on sexual education of young people in general $[10,17,21,28]$, if they are willing to take the responsibility to talk to their children about sex education or if they prefer someone else to do so [5-7] and (3rd) Parents participation in the implementation of sexual education as the most appropriate age at which sexual intercourse begins educating young people with autism $[34,36]$ which is the most appropriate person to undertake sexual education of young people with autism [44] the purpose and content of sexual education programs $[43,44]$ in what ways can parents teach sexual education [13,38], the characteristics that parents need to have to teach children with autism $[6,43]$ points to emphasize sexual education $[1,35]$ the different way that each family faces the issues sexual education $[39,41]$ the issues of sexual education that the same parents consider more important to teach $[27,33]$ whether they consider puberty the most appropriate age to talk about sexual education for their children $[\mathbf{2 8 , 4 1}]$ the reasons why there is no sexual education for young people with autism in Greece [3]. The questions are of the Likert type $[\mathbf{1 8 , 2 2 , 2 9 ]}$ in which the respondent is asked to declare the degree of agreement or disagreement on a five-point graded scale ( $1=$ totally disagree, $2=$ disagree, $3=$ neither disagree nor agree, $4=$ agree and $5=$ totally agree) or there were five options from which respondents should choose one, or Yes/ No options.

\section{Results}

A total of 614 people participated in the present study. 306 of them were parents of children with autism, of whom 116 (37.9\%) were men and 190 (62.1\%) were women and their age ranged from 28-58 years. 308 were parents of children with typical development of whom 137 (44.5\%) were men and 171 were women $(55.5 \%)$ and their age ranged from 28-64 years. 
The mean age of the sample for both groups was 42.3 years. Most of the participants in both groups were married (90.9\%) 9, 8\% were divorced and 2,3\% were unmarried (Table 1).

Regarding the place of residence, $109(36 \%)$ parents of children with autism lived in urban areas, $123(40 \%)$ lived in rural and 74 (24\%) lived in suburban areas. Most of the parents of children with typical development $220(71 \%)$ lived in urban areas, $40(13 \%)$ of them lived in suburban and $48(16 \%)$ lived in rural areas (Table 2).

As far as the educational level, 107 (35\%) parents of children with autism graduated from high school, 80 (26\%) of them graduated from the university, 57 (19\%) from secondary school and $60(20 \%)$ graduated from primary school. Similarly, 95(32\%) parents with typical development children were graduated from high school, 111 (36\%) graduated from the university, 51 (17\%) from primary school and $47(15 \%)$ graduated from secondary school (Table 3).

Regarding their professional status, 115 participants stated civil servants, 170 self-employed, 146 private employees, 86 households, 40 workers and 35 farmers. Specifically, 59 (20\%) parents of children with autism were public servants, 80 (27\%) were freelancers, 57 (19\%) were private employees, 63 (21\%) households, $23(8 \%)$ were farmers and only $15(5 \%)$ were workers, 56 (19\%) parents of children with typical development were public servants, 90 (30\%) were freelancers, 89 (30\%) were private employees, 23 (9\%) households, 25 (7\%) were workers and only 12 (5\%) were farmers (Table 4).

Regarding parental support in the sexual education of

Table 1. Age range, Gender and Marital condition of parents.

\begin{tabular}{lllllll}
\hline & & & \multicolumn{4}{c}{ Marital Condition } \\
\hline & & \multicolumn{2}{c}{ Gender } & Unmarried & Married & Divorced \\
\hline Groups & Age range & Men & Women & N & N & N \\
\hline $\begin{array}{l}\text { Parents of children with autism } \\
\text { Parents of children with typical }\end{array}$ & 28 to 58 & 116 & 190 & 7 & 268 & 30 \\
$\begin{array}{l}\text { development } \\
\text { Total }\end{array}$ & & 137 & 171 & 6 & 280 & 22 \\
& & 253 & 361 & 13 & 548 & 52 \\
\hline
\end{tabular}

Table 2. Place of residence of parents.

\begin{tabular}{llll}
\hline & \multicolumn{3}{l}{ Residence } \\
\hline Groups of parents & Rural & Suburban & Urban \\
\hline Parents of children with autism & N & N & N \\
Parents of children with typical development & 48 & 74 & 109 \\
Total & 171 & 114 & 220 \\
\hline
\end{tabular}

Table 3. Educational level of parents.

\begin{tabular}{lllll}
\hline & $\begin{array}{l}\text { Primary } \\
\text { school }\end{array}$ & $\begin{array}{l}\text { Secondary } \\
\text { school }\end{array}$ & $\begin{array}{l}\text { High } \\
\text { school }\end{array}$ & University \\
\hline Groups & $\mathbf{N}$ & $\mathbf{N}$ & $\mathbf{N}$ & $\mathbf{N}$ \\
\hline Parents of children with autism & 60 & 57 & 107 & 80 \\
Parents of children with typical development & 51 & 47 & 95 & 114 \\
Total & 111 & 104 & 202 & 194 \\
\hline
\end{tabular}

Table 4. Professional status of parents.

\begin{tabular}{lllllll}
\hline & \multicolumn{6}{c}{ Professional status } \\
\hline & $\begin{array}{l}\text { Public } \\
\text { servants }\end{array}$ & Freelancers & $\begin{array}{l}\text { Private } \\
\text { employees }\end{array}$ & Workers & Farmers & Households \\
\hline Groups of parents & $\mathbf{N}$ & $\mathbf{N}$ & $\mathbf{N}$ & $\mathbf{N}$ & $\mathbf{N}$ & $\mathbf{N}$ \\
\hline Parents of children with autism & 59 & 80 & 57 & 15 & 23 & 63 \\
$\begin{array}{l}\text { Parents of children with typical } \\
\text { development }\end{array}$ & 56 & 90 & 89 & 25 & 12 & 23 \\
Total & 115 & 170 & 146 & 40 & 35 & 86 \\
\hline
\end{tabular}


Nikos Apteslis, Journal of Autism 2019,

children or young people with autism, 369 (78\%) of parents from both groups (children with or without autism) had progressive to absolutely progressive aspect, quite progressive had $66(14 \%)$ of them and negative had $49(10 \%)$ of the parents (Graph 1).

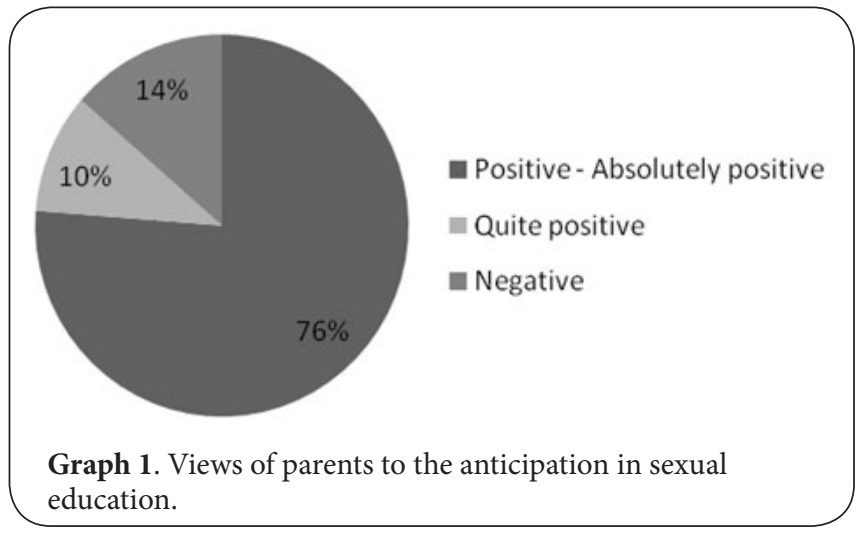

In order to develop Parental Typology of their views on the sexual education of young people with autism, the Hierarchical Analysis was performed in clusters. It revealed 3 clusters/ types of parents (S1, S2, and S3) based on the degree of progressive views they expressed about the sexual education of young people with autism. In the first cluster (S1) were 169 (28\%) parents, in the second cluster (S2) was $86(14 \%)$ of them and in the third cluster (S3) were more numerous 359 (59\%) of parents. We tested the correlation between the three types of parents and gender, age, educational level, place of residence and marital status. Statistically significant correlations were found between parent type (S1, S2, S3), educational level and their age. In particular, S2 and S3 clusters included parents with a higher level of education than parents in cluster S1 (Graph 2).

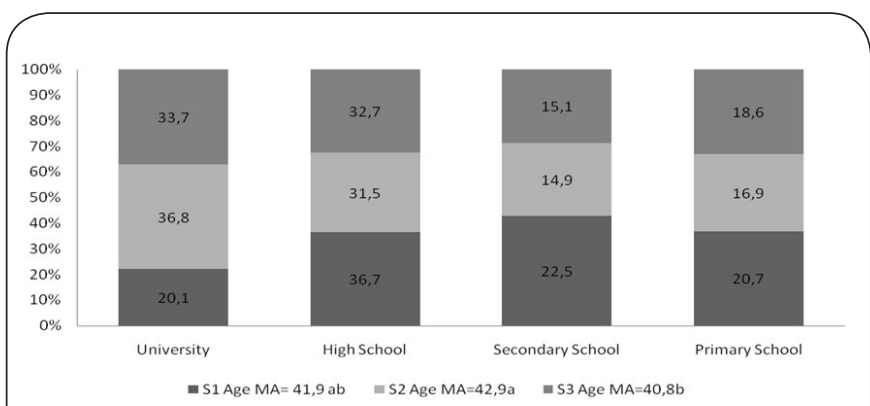

Graph 2. Distribution (\%) of Educational Level of parents and mean age within each Type-Cluster.

The $x 2$ statistical check showed that there is a statistically significant correlation between the parent and their educational level $(x 2=16,166, \beta=6, p=0,014$, Cramer's $V=0,115)$. The variance analysis showed that the age of the parents did not differ significantly between the three types $(F(2,610)=4,773$, $\mathrm{p}=0,009$ ). More specifically, the cluster-type $\mathrm{S} 3$ includes slightly younger parents in relation to the cluster $\mathrm{S} 2$.

Parents' views on the sexual education of young people with autism in relation to their age have shown the following: Means followed by a different letter differ statistically significantly from a significance level of $a=0.05$ according to the LSD criteria (Table 5).

Table 5. Average Parental Age Conditions per Cluster-Type.

\begin{tabular}{llll}
\hline Cluster Type & & $\boldsymbol{M A}^{*}$ & $\boldsymbol{S D}^{* *}$ \\
\hline S1/ Age MA=41,9 ab & 169 & $41,9 \mathrm{ab}$ & 5,9 \\
S2/ Age MA=42,9a & 358 & $42,9 \mathrm{a}$ & 6,2 \\
S3/ Age MA=40,8b & 86 & $40,8 \mathrm{~b}$ & 5,8 \\
\hline
\end{tabular}

${ }^{*}$ Mean ${ }^{* *}$ Standard Deviation

\section{Discussion}

The purpose of the present study was to investigate the views of parents of children with or without autism about the sexual education of children with autism.

The results showed that all parents, regardless they have children with or without autism are positive regarding the sexual education of children with autism. The results consist of some researches which show that nowadays parents in general, believe that all youth people need sex education, regardless children are of typical development or experience difficulties such as mental disabilities or autism $[\mathbf{4 4 , 4 5 ]}$. According to their opinion, sex education will help young people to develop responsible behavior and respect for their mental and physical health and protection. In the present research, parents recognize the need for sexual education of children with autism probably in order to minimize the likelihood of offending behavior and sexual abuse and to provide the teenagers or adults with ASD with the necessary training in order to experience healthy sexuality as typical adolescents and adults do. The result is according to unpublished researches conducted by the University of Queensland in Australia that found that in 1982 only $38 \%$ of parents believed that their child with ASD could have sexual relationships, but in 1991 the percentage rose significantly and reached $85 \%$ of parents [37]. Unfortunately, there is little research in the field and future research should investigate thoroughly that issue.

Also, the results showed that the beliefs of parents of children with and without autism are related to their age and educational level. The results are consistent with studies that have shown that the personal characteristics of parents such as age, educational level, and socioeconomic status influence the attitude toward the sexual education of children with autism $[\mathbf{4 2 , 4 4 ]}$. In the present study, older parents have progressive attitudes about the sexual education of young people with autism. The result may occur due to the fact that older parents have older children and they experienced many difficulties bringing up their children and recognized 
the benefits of sexual education for the quality of life for the individual with autism and for their family, in general. Hence, rendering in the absence of longitudinal studies, it is unclear whether that progressiveness demonstrated by younger age parents arises from a historical shift in their views or occurs because younger parents are more likely to have younger children, and so they did not have to deal with the sexuality of their children. The parents' educational level related to the parents' positive attitudes. Specifically, parents with higher education level had more progressive views on sex education than parents with lower educational level. Results are consistent with previous research that found that the higher the parents' educational level, the more progressive views on sexual education they had $[\mathbf{4 1 , 4 2 ]}$.

In the present research, the views of parents are not related to the place of residence. The results seem to be in contrast with previous research $[15,16]$ reported that parents' attitudes towards people with autism, related to the place of residence and residents of rural areas expressed more traditional views than those living in urban environments $[33,43]$. One reason that the place of residence is not an essential factor in the views on the sexuality of young people with ASD may arise of the fuller information from a variety of media in every part of the country. Possibly, the general population adopted the views on equal rights of people with disabilities $[\mathbf{3 7 , 4 2 ]}$. The results need to be confirmed by future research.

Also, it should be mentioned that the country in which research is taking place is considered as another very important determinant that may influence the views on sexual education of young people with or without autism because of the cultural particularities and the traditions of every country $[3,20]$. Possibly, in modern and progressive societies, residents are positive about the sexual education of young people with or without autism, in contrast to conservative societies where citizens are negative about sex education of young people, regardless of the presence of serious disabilities or not.

\section{Conclusions}

The present research shows that parents of children with or without autism have more progressive views than they did in the past and they believe that young people with autism should get formal sex education. The educational level of the parents related to the positive attitudes according to sex education of people with autism. Parents with higher educational level seemed to have more modern views about the sexual education of people with autism than parents with a lower educational level did. Also, the positive attitudes toward sex education of people with autism may occur from the fact that sexual issues are discussed more often than in the past, possibly in response to the pressure of sexually transmitted diseases. Furthermore, this study shows that the parents of children with or without autism are willing to recognize the important role of sex education for the development of people with disabilities. Also, sexuality education for youth with ASD is essential in order to promote sexual health and prevent negative sexual health outcomes (e.g., unwanted pregnancy, HIV/AIDS or inappropriate sexual behaviors) $[33,34]$. Nevertheless, the importance of providing quality and individualized sex education is substantial because individuals with ASD have unique needs that may not be addressed in sexuality education programs designed for young people of typical development $[1,7,40]$.

\section{Competing interests}

The author declares that he has no competing interests.

\section{Acknowledgements}

I would like to thank all the parents who took part in my research and especially the parents of children with autism because they have been involved in a very serious issue, such as sex education, which is very serious to themselves and their children.

\section{Publication history}

Editor: David Reiss, Imperial College London, UK.

Received: 11-Jan-2019 Final Revised: 15-Mar-2019

Accepted: 18-Mar-2019 Published: 29-Mar-2019

\section{References}

1. Lasgaard M, Nielsen A, Eriksen ME and Goossens L. Loneliness and social support in adolescent boys with autism spectrum disorders. J Autism Dev Disord. 2010; 40:218-26. | Article | PubMed

2. Konstantareas MM and Lunsky YJ. Sociosexual knowledge, experience, attitudes, and interests of individuals with autistic disorder and developmental delay. J Autism Dev Disord. 1997; 27:397-413. I PubMed

3. Kakavoulis A and Forrest J. Attitudes and values in sexual behavior and sex education: A cross-cultural study among university students in Greece and Scotland. International Review of Education. 1999; 45:137151.

4. Young R, Gore $\mathrm{N}$ and McCarthy M. Staff attitudes towards sexuality in relation to gender of people with intellectual disability: a qualitative study. J Intellect Dev Disabil. 2012; 37:343-7. I Article I PubMed

5. Hellemans H, Colson K, Verbraeken C, Vermeiren R and Deboutte D. Sexual behavior in high-functioning male adolescents and young adults with autism spectrum disorder. J Autism Dev Disord. 2007; 37:260-9. | Article | PubMed

6. Bernert DJ and Ogletree RJ. Women with intellectual disabilities talk about their perceptions of sex. J Intellect Disabil Res. 2013; 57:240-9. I Article I PubMed

7. Murphy GH. Capacity to consent to sexual relationships in adults with learning disabilities. J Fam Plann Reprod Health Care. 2003; 29:148-9. | Article I PubMed

8. Balogh R, Bretherton K, Whibley S, Berney T, Graham S, Richold P, Worsley $\mathrm{C}$ and Firth $\mathrm{H}$. Sexual abuse in children and adolescents with intellectual disability. J Intellect Disabil Res. 2001; 45:194-201. I PubMed

9. Gilmour L, Schalomon PM and Smith V. Sexuality in a community-based sample of adults with the autism spectrum disorder. Research in Autism Spectrum Disorders. 2012; 6:313-318.

10. Baron-Cohen S, Knickmeyer RC and Belmonte MK. Sex differences in the brain: implications for explaining autism. Science. 2005; 310:819-23. | Article I PubMed

11. Brook. Living your life: The sex education and personal development resource for people with learning difficulties and disabilities. London, Brook. 2011.

12. Ballan M. Parents as sexuality educators for their children with developmental disabilities. SIECUS Reports. 2001; 29:14-19.

13. Marriage S, Wolverton A and Marriage K. Autism spectrum disorder grew up: A chart review of adult functioning. Journal of the Canadian 
Nikos Apteslis, Journal of Autism 2019,

Academy of Child and Child Adolescent Psychiatry. 2009; 18:322-328.

14. Baron-Cohen S. Mindblindness: An essay on autism and theory of mind. Cambridge, MA, US: The MIT Press. 1995

15. Coombs-Richardson R and Meisgeier C. Connecting with Others: Lessons for Teaching Social and Emotional Competence Grades 9-1. 2001

16. Taleporos $G$ and McCabe M. P. The impact of physical disability on body esteem. Sexuality and Disability. 2001; 19:293-308.

17. Anne Marie Johnson B.S. Ed. More Social Skills Stories: Very Personal Picture Stories for Readers and Nonreaders K-12. 1999.

18. Norusis M. SPSS Profesional Statistics 6.1. Chicago Press: SPSS Inc. 1992.

19. Haracopos D and Pedersen L. Sexuality and Autism. Stockholm: Riksföreningen Autism. 1997.

20. Matinopoulou Y. Experience, problem, and opinion of families who have a child with a learning disability. 1990; 19:145-157.

21. Kakavoulis A. Family and Sex Education: a survey of parental attitudes. Sex Education. 2001; 1:163-174. I Article

22. Nunnally J.C. Psychometric Theory. New York: McGraw Hill Book Co. 1978.

23. Obaydi $\mathrm{H}$ and Puri BK. Prevalence of premenstrual syndrome in autism: a prospective observer-rated study. J Int Med Res. 2008; 36:268-72. Article | PubMed

24. Hellemans H, Colson K, Verbraeken C, Vermeiren R and Deboutte D. Sexual behavior in high-functioning male adolescents and young adults with autism spectrum disorder. J Autism Dev Disord. 2007; 37:260-9. | Article | PubMed

25. Attwood T. Theory of mind and Asperger's syndrome. Lawrence Erlbaum Associates Publishers. 2005.

26. Lasgaard M, Nielsen A, Eriksen ME and Goossens L. Loneliness and social support in adolescent boys with autism spectrum disorders. J Autism Dev Disord. 2010; 40:218-26. | Article | PubMed

27. Hofvander B, Delorme R, Chaste P, Nyden A, Wentz E, Stahlberg O, Herbrecht E, Stopin A, Anckarsater H, Gillberg C, Rastam M and Leboyer $M$. Psychiatric and psychosocial problems in adults with normalintelligence autism spectrum disorders. BMC Psychiatry. 2009; 9:35. | Article | PubMed Abstract | PubMed FullText

28. Murphy $\mathrm{N}$ and Elias $\mathrm{E}$. The sexualityy of children and adolescents with developmental disabilities. Paediatrics. 2006; 118:398-403. I Article

29. Jamieson S. Likert Scales: How to (ab) Use. Medical Education. 2005; 38:1217-8. | Article

30. Fine $M$ and McClelland S. Sexuality Education and Desire: Still Missing After All These Years. Harvard Educational Review. 2006; 73:297-473.

31. Government affairs the Hellenic Republic. Law 3699/2008. Special Education and Education of Disabled persons or Special Educational Needs. 2008.

32. Mehzabin Priyankaa, Stokes and Mark A. Self-Assessed Sexuality in Young Adults with High-Functioning. Autism Research in Autism Spectrum Disorders. 2011; 5:614-621.

33. Dawson G, Webb S.J, Estes A, Munson J and Faja S. Electrophysiological indices of altered emotional face processing in parents of children with autism. 2008

34. Shattuck $P$ and Grosse S. Issues related to the diagnosis and treatment of autism spectrum disorder. Mental Retardation and Developmental Disabilities. 2007; 13:129-35. | Article

35. SIECUS. Issues and answers fact sheet on sexuality education. New York: Sexuality Information and Education Council of the United States, August/September. 1999; 29-33.

36. American Psychiatric Association. Diagnostic and Statistical Manual of Mental Disorders (DSM-5). 2013.

37. Attwood T, Hénault I and Dubin N. The autism spectrum, sexuality and the law: What every parent and professional needs to know. London: Jessica Kingsley Publishers. 2014.

38. Ballan MS. Parental perspectives of communication about sexuality in families of children with autism spectrum disorders. J Autism Dev Disord. 2012; 42:676-84. | Article | PubMed
39. Byers ES, Nichols S and Voyer SD. Challenging stereotypes: sexual functioning of single adults with high functioning autism spectrum disorder. J Autism Dev Disord. 2013; 43:2617-27. | Article | PubMed

40. Koller R. Sexuality and adolescents with autism. Sexuality and Disability. 2000; 18:125-135.

41. Nichols S and Blakeley-Smith A. "I'm not sure we're ready for this...": Working with families toward facilitating healthy sexuality for individuals with autism spectrum disorders. Social Work in Mental Health. 2010; 8:72-91.

42. Travers $J$ and Tincani M. Sexuality education for individuals with autism spectrum disorders. Critical issues and decision-making guidelines. Education and Training in Autism and Developmental Disabilities. 2010; 45:284-293. | Article

43. Van Bourgondien ME, Reichle NC and Palmer A. Sexual behavior in adults with autism. J Autism Dev Disord. 1997; 27:113-25. I PubMed

44. Wolfe P.S, Condo B and Hardaway E. Sociosexuality education for persons with autism spectrum disorders using principles of applied behavior analysis. Teaching Exceptional Children. 2009; 42:50-6170.

45. Sexuality Information and Education Council of the United States. Position Statements. 2012.

Citation:

Apteslis N. The View on the Sexual Education of People with Autism in Modern Greek Society.

J Autism. 2019; 6:2.

http://dx.doi.org/10.7243/2054-992X-6-2 